\title{
The Herd Health Handbook for Goat Producers: Control of Parasites in Goats ${ }^{1}$
}

Ray Mobley, Carmen Lyttle-N'guessan, and Thomas Peterson²

\section{Introduction}

Parasites are a major cause of health problems in goats. They cause the animals to be unthrifty which may include the loss of weight, low birth weights, and difficulty kidding. Parasites may also cause the animals to be susceptible to other medical problems and death. The control of parasites is essential for the proper management of the goat herd.

Goats are susceptible to external and internal parasites. External parasites (ecto-parasites) that affect goats include lice, ticks, and mange mites. There are two classes of internal parasites that affect goats: large round worms (helminthes) and protozoa (coccidia). Proper control of these parasites is very important because they can cause great damage to an infected herd.

\section{Effect of External Parasites on Goat Health and Production}

External parasites can transmit diseases from sick to healthy animals. They can reduce weight gains and milk production; in severe cases, external parasites can cause death of the animal. Although there are multiple species of external parasites, the management techniques to control many species of external parasites are similar. It is important to control external parasites because they may serve as vectors for transmitting diseases.

\section{Effect of Internal Parasites on Goat Health and Production}

Internal parasite infestations of herds can cause major health issues, which have a major effect on the animal's performance and cause great economic loss to the producer. In fact, most of the economic losses caused by internal parasites are actually not due to mortality but production loss. The proper management of internal parasites is extremely important to the success of the goat producer.

\section{Common Internal Parasites in Florida}

\section{A) Coccidia}

Coccidiosis is caused by small unicellular parasites unable to be seen by the naked eye. Most are host specific, which means each type can only affect one species of animal. The life cycle of coccidia is the following: The oocysts pass in the feces of the host, then it sporulates in the environment to produce infective sporocyst containing sporozoites. The sporocysts are ingested by the host. The sporozoites are released and they enter the cells, where they mature, reproduce, multiply and form new oocysts. All ages of goats may be infected, but the highest incidence of infestation is found in young goats between 3 weeks and 5 months of age. The factors that affect the frequency and intensity of infection include the condition of the host, the parasite management plan of the producer, and environmental factors.

\section{Symptoms of Coccidia Infection}

1. Diarrhea (unpelleted feces followed by pasty, watery, yellow-green to brown feces)

2. Poor growth

3. Weight loss

4. Depressed appetite

5. Listlessness

${ }^{1}$ This document is FAMU003, part of the Goat Herd Health Handbook, a series from Florida A\&M University, Florida Cooperative Extension Service, Institute of Food and Agricultural Sciences, University of Florida. Original publication date September 2009. Visit the EDIS Web Site at http://edis.ifas.ufl.edu.

${ }^{2}$ Ray Mobley, director, Cooperative Extension; Carmen Lyttle-N'guessan, veterinary care manager; Thomas Peterson, extension veterinarian; Florida A\&M University, College of Engineering Sciences, Technology and Agriculture, Cooperative Extension Programs; Florida Cooperative Extension Service, Institute of Food and Agricultural Sciences, University of Florida, Gainesville, FL 32611.

The Institute of Food and Agricultural Sciences (IFAS) is an Equal Opportunity Institution authorized to provide research, educational information, and other services only to individuals and institutions that function without discrimination with respect to race, creed, color, religion, age, disability, sex, sexual orientation, marital status, national origin, political opinions, or affiliations. U.S. Department of Agriculture, Cooperative Extension Service, University of Florida, IFAS, Florida A\&M University Cooperative Extension Program, and Boards of County Commissioners Cooperating. Millie Ferrer-Chancy, Interim Director 
6. Weakness

7. Abdominal pain

8. Sudden death

\section{Treatment for Coccidia Infection}

Coccidiosis is treated by quarantining or isolating the infected animal, replacing the fluids lost by diarrhea, feeding the animals small amounts of food, injection of an hematinic (iron, vitamin B12) and administering of anticoccidial drugs (usually sulfa-based medications). Table 1 contains the generic and brand names of many coccidiostats that are commercially available. Coccidiosis can be controlled by isolation of new and sick animals, traffic control, proper stocking rates, and most importantly good sanitary practices.

Table 1. Generic and Brand Names of Common Coccidiostats

\begin{tabular}{|l|l|}
\hline Generic Name & \multicolumn{1}{|c|}{ Brand Name } \\
\hline Monensin & Rumensin $\mathbb{C}$ \\
\hline Lasalocid & Bovatec $\mathbb{C}$ \\
\hline Decopuinate & Deccox $\mathbb{C}$ \\
\hline Amprolium & Corid@ \\
\hline Sulfadimethoxine & Albon $\subset$ \\
\hline
\end{tabular}

\section{B) Heminthes (round worms)}

There are many different intestinal round worms (nematodes or helminthes) that affect goats. The most common and problematic worms are Haemonchus contortus and Telodorsagia circumcincta. All have direct life cycles. The egg is passed in the feces of the host. The larvae mature until they reach the infective stage. They are ingested by the goat during the consumption of contaminated forage when grazing, most likely during the mornings and evenings when larvae migrate to the top of grass. After ingestion, the larvae develop to adult worms in the abomasum, small intestine, cecum, or colon based on species of worm. Infections usually are mixed (caused by multiple species of parasites). Young grazing animals tend to be more at risk.

\section{Symptoms of Helminthes infection:}

1. Progressive loss of condition

2. Poor growth

3. Dull attitude

4. Decrease in feed intake

5. Dark green to black diarrhea with staining of the rectal area
6. Intermandibular edema (bottle jaw)

7. Pot belly

8. Rough coat

9. Flaky skin

10. Anemia

11. Death

\section{Treatment of Helminthes}

Internal parasites are treated with anthelminthics. There are numerous choices of anthelminthics. Table 2 contains the generic name and the brand name of many of the types of anthelmintics that are commercially available. When using anthelminthics, it is important to observe the withdrawal times recommended by manufacturers for animals that are to be sold or sent to slaughter.

Table 2. Generic and Brand Names of Common Anthelminitics

\begin{tabular}{|l|l|}
\hline \multicolumn{1}{|c|}{ Generic Name } & \multicolumn{1}{c|}{ Brand Name } \\
\hline Ivermectin Drench & Ivermectin Drench $\mathbb{C}$ \\
\hline Ivermectin Injectible & Ivomec $\mathbb{C}$ \\
\hline Eprinomectin & Eprinex $\mathbb{C}$ \\
\hline Doramectin & Dectomax $\mathbb{C}$ \\
\hline Moxidectin & Cydectin $\mathbb{C}$ \\
\hline Albendazole & Valbazen $\mathbb{C}$ \\
\hline Fenbendazole & PanacurC/Safegaurd $\mathbb{C}$ \\
\hline Oxfendazole & Synanthic $\mathbb{C}$ \\
\hline Levamisole & Levasole $\mathbb{C}$ \\
\hline
\end{tabular}

\section{Preventative Measures in Controlling Internal Parasites Infestation}

In order to control infection of internal parasites, it is important to maintain good stocking rates (8-10 animals per acre), practice appropriate pasture rotation, and do selective deworming, which includes the use of the FAMACHA ${ }^{\mathbb{C}}$ System. Other suggested control measures include: turning the soil in temporary pastures, co-grazing, avoiding overgrazed pastures, growing different crops on the pastures in between grazing, avoiding the mixed grazing of young and old animals, and removing manure piles. 


\section{How to Use the FAMACHAC System}

The FAMACHAC system involves checking the color of the mucous membrane of the lower eyelid in order to determine the extent of anemia; and thus, the level of infection by H. contortus (only). The technique was developed in South Africa and validated by studies in the United States. The system categorizes animals on a scale of 1 to 5 , with 5 being reserved for the most anemic animals. One of the advantages of the FAMACHAC system is that it decreases the number of animals that are treated by targeting animals that show physical signs of infection with $\mathrm{H}$. contortus. This system of diagnosis lowers production cost, identifies worm--susceptible animals that should be culled, and slows the development of anthelmintic resistance. Although the procedure is simple, quick, and easy to do, it is important that the producer be trained by a veterinarian or other trained animal health professional to use the FAMACHA ${ }^{\mathbb{C}}$ system accurately.

\section{Conclusion}

Although the control of parasites can be a daunting task, a management scheme that includes smart choices based on sound, science-based facts can lead to a healthy, profitable herd. With challenges such as the rise of resistance of parasites to drugs and the high cost of these drugs, one of the most significant aspects in the control of parasites is to prevent parasite infestations. This task can be accomplished by decreasing the animal's exposure to the parasites through management techniques similar to those previously discussed, sanitation, and selecting animals that are genetically more resistant to infection.

Lastly, it is important to consult with a veterinarian about proper diagnosis and treatment of infection since the symptoms of parasite infection are similar to other diseases and many drugs used to treat parasites are not approved for use in goats.

Special thanks to Dr. James Miller, Louisiana State University, for his suggestions.

\section{References:}

Coffey, L., Hale, M., \& Wells, A. Goats: Sustainable production overview-Livestock production guide. NCAT Agricultural Specialist. http://attra. ncat.org/attra-pub/PDF/goatoverview.pdf. Received on July 21, 2009.

http://www.vet.utk.edu/departments/LACS/pdf/ FAMACHA.pdf. Received on August 10, 2009. Merck \& Company, Inc. (2008). Health-manage- ment interaction: Goats. The Merck Veterinary Manual. Received July 21, 2009.

Pugh, D. G. (2002). Sheep and goat medicine, 1st ed. pp. 210-211 \& 397-398. Saunders, Philadelphia.

Smith, M. C., \& Sherman, D. M. (1994). Goat Medicine. pp. 312-345, Lippincott Williams \& wilkins Wolters Kluwer company. 